\title{
'Matter Matters': Topographical and Theological Space in the Poetry of Norman Nicholson
}

\author{
DAVID GOOPER
}

Lancaster University

\begin{abstract}
I would make a poem
\end{abstract}
Solid as a stone, a thing

You can take up, turn, examine and put down

$(\text { Norman Nicholson) })^{1}$

Writing in 1956, the Faber poet Norman Nicholson (19I4-87) asserted that 'Christianity is one of the most materialist of religions. It holds that matter matters'. ${ }^{2}$ This article will explore how a Christian understanding of phenomena informs Nicholson's own poetic practice and underpins his inextricable intertwining of theological and topographical concerns. Drawing upon recent theoretical developments in both literary and theological studies, the essay will focus on Nicholson's first three collections - Five Rivers (1944), Rock Face (I948), and The Pot Geranium (1954) - and highlight the writer's exploration of a range of strategies for developing a Christian poetry of place and space. ${ }^{3}$ It will argue that Nicholson, in his early work, moves towards an incarnational poetics that is predicated upon a phenomenological understanding of being and dwelling; and central to this discussion will be an examination of the way in which a dialectic of spatial boundedness and boundlessness underpins, and problematizes, Nicholson's expression of what it means to be-in-the-world. Through a spatialized reading of Nicholson's Christian poetry, this article hopes to open up conceptual thinking about a writer whose work was supported and published by T. S. Eliot, but who presently occupies a peripheral position within the history of twentieth-century British and Irish poetry.

Nicholson first came to the attention of a national readership as an explicitly Christian anthologist and critic of modern literature. In I942 he edited An Anthology of Religious Verse, a collection that was subtitled 'Designed for the Times' and

\footnotetext{
1 'Poem', in Norman Nicholson: Collected Poems, ed. by Neil Curry (London: Faber and Faber, 1994), p. 408.

2 Norman Nicholson, 'Tell It Out among the Heathen: The Christian Poet Today', Christian Neves-Letter, 4 (1956), 33-8 (p. 34).

3 For a brief introduction to the 'spatial turn' in literary studies see David Cooper, 'The Poetics of Place and Space: Wordsworth, Norman Nicholson and the Lake District', Literature Compass, 5 (2008), 807-21. An overview of the 'spatial turn' in theological studies is provided in Sigurd Bergmann, 'Theology in its Spatial Turn: Space, Place and Built Environments Challenging the Images of God', Religion Compass, I (2007), 353-79.
} 
proved to be popular with war-time readers. In the brief introduction to the Anthology, Nicholson sets out his pluralistic editorial approach, highlighting how he aims to use the textual space to show 'Roman Catholic, Anglican and NonConformist, or even pagan, buddhist [sic] or sceptic, looking at the same thing each from his own point of view'. ${ }^{4}$ Yet, in spite of this democratic declaration, the collection opens with an extract from Eliot's Murder in the Cathedral (I935) and remains dominated by the voices of male poets working within a (broadly defined) Christian tradition: Hopkins, Chesterton, Lawrence, and, significantly, both Eliot and Auden. In the following year SCM Press published Man and Literature, a critical monograph that emerged out of a series of lectures Nicholson had delivered for the Workers' Educational Association in his native county of Cumberland. ${ }^{5}$ Nicholson introduces the study by arguing that he is not seeking 'to measure modern literature by a Christian yardstick'. ${ }^{6}$ Yet the influence of Eliot permeates the monograph, and Nicholson's readings of Edwardian and modernist writing clearly represent an attempt to satisfy the demand - voiced in Eliot's i935 essay 'Religion and Literature' — for 'Christian readers to scrutinise reading, especially of works of imagination, with explicit ethical and theological standards'. ${ }^{7}$ What is more, Nicholson implicitly draws upon the thinking of Charles Williams in constructing an idealized model of Christian poetry based on the principles of the Affirmative Way. It is a theological position that emerges as a dominant characteristic of Nicholson's critical practice and goes on to inform his later reading of Wordsworth's 'acceptance of the entire beauty of the created world, of the essential rightness and righteousness of matter'. ${ }^{8}$

It was the writing of poetry, however, that provided Nicholson with the imaginative environment in which to explore his emerging religious beliefs and uncertainties. More specifically, Nicholson perceived poetry as a site in which he was able to question what it means to be a Christian dwelling in, and moving through, the material world of everyday spatial practice. Nicholson's nascent conception of poetry as a medium in which to examine the relationship between faith and experience is evident in the early poem 'Now That I Have Made my Decision', which was written in I940, following Nicholson's return to full

\footnotetext{
${ }^{4}$ Introduction to An Anthology of Religious Verse: Designed for the Times (Harmondsworth: Penguin, I942), ed. by Norman Nicholson, pp. ix-x (p. x).

${ }^{5}$ Following regional boundary changes in I974, the old counties of Cumberland, Westmorland, and part of north Lancashire were united within the new administrative territory of Cumbria. However, as Nicholson explains in one of his topographical prose books, Greater Lakeland (London: Robert Hale, I969), the label 'Cumbria' was not a twentieth-century neologism but can be traced back to the 'early Celtic inhabitants of the Lakes', who belonged 'not to the Irish but to the Welsh or Brythonic branch of the Celts' (p. I6). This essay will follow the Nicholsonian practice of moving between the labels 'Cumberland' and 'Cumbria'.

${ }^{6}$ Norman Nicholson, Introduction to Man and Literature (London: SCM Press, I943), pp. 5-6 (p. 5).

7 T. S. Eliot, 'Religion and Literature', in T. S. Eliot: Selected Essays, grd edn (London: Faber and Faber, 195I), pp. 388-40I (p. 388).

${ }_{8}$ Introduction to Wordsworth: An Introduction and a Selection, ed. by Norman Nicholson (London: Phoenix House, I949), pp. ix-xxvi (p. xxiii).
} 
communicant membership of the Church of England, but was not published until I994, in the posthumous Collected Poems. The poem begins with the young writer unambiguously establishing the Christian foundations for his literary aspirations: 'NOW THAT I HAVE MADE MY DEGISION and felt God on my tongue | It is time that I trained my tongue to speak of God'. ${ }^{9}$ In these lines, the embryonic poetic career is set out in quasi-monastic terms of self-discipline and dedication; and, significantly, the 'decision' is described as a sensuous experience, as the word of God is said to have been 'felt' on the body. Further on in the poem, the interweaving of the literary and the religious is enriched as Nicholson indicates that the localized experience of place will be integral to the further development of his poetic project: 'It is time that I cease to stare towards the horizon for a goal, | But gear my gaze to the near path cogged out for my soul' (p. 406). Nicholson voices a relinquishment of unnecessary and futile ambition in order to focus exclusively on the textural actuality of his immediate environment; that is to say, he draws upon his Christian belief to accept a life of physical locatedness. As a result, the poem seems to confirm Nicholson's preoccupation with the Affirmative Way and his predilection for writing that celebrates 'the achievements of simple lives'. ${ }^{10}$ A doubt is raised, however, by the use of the mechanistic verb 'cogged', which intimates that this rootedness has been preordained rather than self-determined. The image of enforced fixity is a core feature of Nicholson's spatial poetics; and, read in biographical terms, it is an image that can be traced back to the tuberculosis of the larynx that he contracted during his teenage years and subsequently led to his spending the rest of his life in his home town of Millom on the south-western fringes of the Lake District. As a result, 'Now That I Have Made my Decision' foregrounds Nicholson's interest in the personalized relationship between (spiritual) liberation and (physical) boundedness.

Although the relationship between the topographical and the theological provides the thematic foundation for much of Nicholson's early writing, his first major publications do not develop the first-person spatial poetics set up by 'Now That I Have Made my Decision'. Instead, Nicholson moves out from the self and adopts a mode of detached documentation when endeavouring to articulate a Christian understanding of landscape and environment. In the I940s Nicholson contributed to the Christian verse drama revival that had begun with Eliot in the previous decade and included Anne Ridler, Ronald Duncan, and Christopher Fry among its key practitioners. Significantly, three of Nicholson's four verse plays — The Old Man of the Mountains (1945 $\left.{ }^{[\text {Copy-ed1] }}\right), A$ Match for the Devil (1953), Birth by Drowning (1959) — are founded on the basic conceit of

\footnotetext{
9 'Now That I Have Made my Decision', in Collected Poems, p. 4o6. Further references to this poem will be given in the text.

${ }_{10}$ Nicholson, Man and Literature, p. 214.
} 
resituating biblical narratives into the writer's native county of Cumberland. ${ }^{11}$ It is a spatializing device that can also be traced in Nicholson's early poetry: the first of the three theological-topographical tropes that this essay will identify. Yet, in turning away from the self and moving towards a mode of biblical transplantation, Nicholson's early geo-poetry highlights the tensions between Christian belief and everyday spatial practice.

Nicholson's debut volume, Five Rivers, opens with a sequence of geo-specific poems — 'Five Rivers', 'Egremont', 'Cleator Moor', 'Whitehaven', 'St Bees', 'Eskmeals I943' - that allows him both to position his own writing within the canonical tradition of place-name poetry and, at the same time, to articulate an imaginative appropriation of a particular tract of land. ${ }^{12}$ Surprisingly, perhaps, Nicholson's home town of Millom is not named once in this series of topographical poems. In spite of the pledges voiced in 'Now That I Have Made my Decision', Nicholson does not focus on the embodied experience of his immediate local environment, but his primary objective, rather, is to provide a textual mapping of regional space through a composite portrait of the county of Cumberland. In the first poem of the collection, 'Five Rivers' (pp. 7-8), the opening lines announce a mode of literary cartography: 'Southward from Whitehaven, where cliffs of coal | Slant like shale to the low black mole'. With these lines Nicholson begins to determine the geographical parameters of his own poetic territory, and he declares his interest in an area that contains both industrial and rural topographies — one in which the River Ehen is 'stained with the blood of the ore | Of the mines of Egremont and Cleator Moor' (p. 7) and in which the Esk 'knows the stonechat and the parsley fern | And breaks like a bottle at every turn' (p. 8).

The poem 'Egremont' (pp. 9-Io) feeds into this textual mapping of region and presents images of a 'buttressed, tunnelled, turretted' industrialized topography defined by the presence of 'chimneys, pit-shafts, rubble-tips'. At the same time, it is a text that exemplifies the problems associated with Nicholson's attempted conflation of the geographical and the theological. For the most part, 'Egremont' offers a straightforward, third-person description of the named place; and Nicholson's portrait of the town can be seen to be underpinned by the desire to offer a revisionist, post-Romantic representation of his native region. More particularly, the portrait of place is shaped, at least in part, by Nicholson's engagement with Auden's imaginative rejection of the seemingly petrified landscape of fells and tarns, crags and becks, associated with the

11 Nicholson's second verse play, Prophesy to the Wind, was written in 1947 but first performed in I949. All four were published in London by Faber and Faber, in I946, I950, I955, and I96o respectively. The dates listed above refer to the first performance dates. For a comprehensive performance history of each play see Philip Gardner, Norman Nicholson (New York: Twayne, I973), pp. II I-53.

${ }_{12}$ Norman Nicholson, Five Rivers (London: Faber and Faber, 1944), pp. 7-15. Further references to individual poems within this collection (hereafter abbreviated to $F R$ ) will be given in the text. 
Wordsworthian Lake District: 'Clearer than Scafell Pike, my heart has stamped on | The view from Birmingham to Wolverhampton'. ${ }^{13}$ In an interview with the poet David Wright in I985, Nicholson suggested that Auden's 'attitude to the industrial scene' was 'romantic' and 'slightly ironic at the same time'; 14 the emphasis in Nicholson's early industrial poetry, however, lies in the direct, detached documentation of the local landscape. This leads Nicholson to focus on the environmental threat represented by local mining: 'And rock and bones are broken both | When the stone spine is theft from earth' (p. io). 'Egremont' thereby highlights a fundamental tension in Nicholson's poetry of place. In one sense he uses the industrial terrain to offer a twentieth-century reconfiguration of region; by concentrating on 'the pit-heaps' of Egremont (p. Io), Nicholson offers a vision of Cumbria that modulates the green Romanticism of Wordsworth's poetic documentation of place. Yet, at the same time, Nicholson articulates what can be described as an 'ecopoetical' concern for the irreversible ruination of the land: 'The crime defiles like a red mud | The ore, the sandstone, and the blood' (p. io). ${ }^{15}$

It is not until the final lines of 'Egremont', however, that the Christian foundations for Nicholson's spatial thinking are made explicit - a sudden shift in emphasis that leads to what Philip Gardner describes as an 'apocalyptic, deusex-machina ending': 16

But the robbed earth will claim its own
And break the mines and castle down
When Gabriel from heaven sent
Blows the Horn of Egremont,
Tabulates the tenants' needs
And reassumes the title-deeds. (p. Io)

In this final stanza Nicholson's portrait of place is layered further, in that his familiarity with Wordsworth's poem 'The Horn of Egremont Castle' leads him to envision the named town as an intertextual space. Once again, therefore, Nicholson can be seen to be positioning his own work within a clear line of English place-name poetry, although, simultaneously, his own representation of place moves away from what has gone before. In an explanatory footnote Nicholson indicates that Wordsworth's poem is based on the tradition that 'the Horn of Egremont can be blown only by the rightful owner of the castle' (p. io). As a result, Wordsworth's text is concerned with the interrelated issues of land

\footnotetext{
13 W. H. Auden, 'Letter to Lord Byron', in Collected Poems, ed. by Edward Mendelson (London: Faber and Faber, I976), pp. 75-10o (p. 82).

14 'Norman Nicholson in Conversation with David Wright', PN Review, I2 (I985), 4I-4 (p. 42).

15 The term 'ecopoetical', which has become integral to ecocritical discourse and practice, is used by Jonathan Bate to define a Heideggerian understanding of the way in which 'a poem may be a making (Greek poiesis) of the dwelling-place'; see Jonathan Bate, The Song of the Earth (London: Picador, 200o), p. 75.

16 Gardner, p. 45.
} 
ownership and familial history: 'And through ages, heirs of heirs, | A long posterity renowned'. ${ }^{17}$

In contrast, Nicholson's 'Egremont' ends with an eschatological allusion as the poet imagines the moment when the archangel Gabriel will be sent down to the landscape of industrial Cumberland. Nicholson anticipates the judgement of those who have 'defile[d]' the living-space created by God, and, as a result of this shift in focus, he opens up the possibility of an eco-theological interpretation of this geo-specific poem that appears to privilege green space over the worked terrain. In 'Egremont', then, Nicholson sets up a tripartite spatial hierarchy: the anthropological space of the built environment; the God-given space of the organic landscape on and in which the mines have been constructed and excavated; and, on the highest tier, the abstract, theological space from which Gabriel will be sent to earth. Following Gardner's implicit critique of 'Egremont', the importation of Gabriel could be seen to be representative of the imaginative problems Nicholson frequently experienced with the closure of essentially narrativeless, third-person documentary recordings of place. ${ }^{18}$ Instead of treating the device as an imaginative deficiency, however, the introduction of Gabriel could be read as part of an ongoing process in which Nicholson uses poetry to find a way of integrating Christian belief into the everyday. 'Egremont', therefore, is a poem in which Nicholson begins to explore his understanding of the relationship between different types of material and abstract space.

A similar spatializing strategy is adopted in another place-name poem in Five Rivers. In 'Whitehaven' (pp. I2-I3) Nicholson describes the titular Georgian town as a liminal site located at 'the Atlantic's dying edge'; he presents this planned built environment as a labyrinth in which 'Deep as trenches streets are dug | Beneath entanglements of fog'. As well as introducing the reader to the geography of contemporary Whitehaven, Nicholson is also preoccupied with the spatial history concealed within 'the walls', 'street[s]' and 'pavements' of 'this beleaguered town' (p. I3). He specifically reflects upon the attempted invasion of Whitehaven infamously led by 'John Paul Jones, the Yankee-Scot, | Apprentice from Kirkcudbrightshire' in I778: 'He came at spring tide from the west, | The setting sun behind his mast' (p. I2). As a result, 'Whitehaven' can be read as an

17 William Wordsworth, 'The Horn of Egremont Castle', in The Poetical Works of William Wordsworth, 5 vols, ed. by E. de Selincourt (vols 2-3 with Helen Darbishire) (Oxford: Clarendon Press, I940-49), Iv (I947), I69-72 (p. I72).

${ }_{18}$ Nicholson's difficulties with poetic closure can be explored further through examination of the original manuscript material in the Norman Nicholson Archive, John Rylands Library, University of Manchester, as well as the papers held by the British Library. For a brief discussion of the Nicholson Archive see Stella Halkyard, 'Archive Corner 4: Making a Little Room an Everywhere', PN Review, 33 (2007), I3-I5. My own doctoral thesis offers a spatial analysis of Nicholson's compositional process, placing particular emphasis on the relationship between the writer's geographical situatedness and his drafting of poems, and on the materiality of his chosen manuscript spaces; David Cooper, 'Staying Put: Norman Nicholson and the Poetics of Place and Space' (unpublished doctoral thesis, Lancaster University, 2007), pp. 26o-82. 
exercise in poetic archaeology; it is an attempt to reach an understanding of what Nicholson identifies to be the 'cold suspicion' associated with this particular place and its people (p. I3). Yet, as with 'Egremont', the poem ends with the seemingly incongruous image of Gabriel descending upon the earthly environment:

Gabriel, the brigand, guides

His fiery frigate down the clouds,

Tears up the lighthouse in his hand

And waves it like a burning brand (p. I3)

Ultimately, Nicholson imagines how the merchants will 'sell the town | To make the bartered souls their own', and will, 'Hoist high their white flag in the sky | And yield to heaven's piracy' (p. I3). It is a final verse that corresponds with 'Egremont' in that Gabriel is once again introduced to underscore the intrinsically transient nature of the human occupation of earthly space. What is more, the poem reinforces the three-tiered spatial model, as Nicholson registers a belief that the everyday spatial practices of the people of Whitehaven are based upon both a delusional privileging of anthropological over organic space and an apparent disregard for that divine space which remains immaterial. Through the importation of Gabriel into mid-twentieth century west Cumberland, Nicholson sets up a configuration in which the clearly defined, enclosed spaces of Whitehaven's built environment - the trench-like streets, the harbour, the mine shafts - are subordinated to the God-given space in which they have been constructed.

Elsewhere in Five Rivers Nicholson expands his attempt to perceive the Cumbrian terrain in theological terms through the transportation of Old Testament narratives into localized environments. In 'The Raven' (p. 47), for example, Nicholson's relocates I Kings i 7 to an unnamed landscape; but through the use of regional vocabulary — 'the black tarn', 'upland dykes and slate and cobble walls', 'the fells' — it is clear that the generic setting is rural Cumbria. The poem begins with a description of how the 'raven flew above the screes, above the rocks | Where the bare bones of the mountain broke through the skin', before going on to feed an 'old man with a beard white as may' (Elijah) with bread that had been 'scattered' by 'the farmer's wife' outside their 'farm beyond the mosses' (p. 47). In a mode analogous to the contemporaneous paintings of Stanley Spencer, the Old Testament narrative is domesticated through the use of a recognizably regional setting; biblical abstractions are particularized through an emphasis on everydayness. ${ }^{19}$

\footnotetext{
${ }^{19}$ In spite of his relative socio-spatial isolation in Millom, Nicholson's modes of landscape perception and representation frequently correspond with, and are influenced by, the thinking and practices of contemporary visual artists. In addition to Nicholson's imaginative intersections with Spencer, the poet's representation of region chimes with the St Ives artists and, in particular, the geo-specific paintings of Peter Lanyon. More locally, Nicholson had personal connections with a number of Cumbrian artists, including Percy Kelly and Sheila Fell; and, through the patron of the arts Helen Sutherland, he also became acquainted with Ben and Winifred Nicholson and their respective work.
} 


\section{I76 Topographical and Theological Space in Nicholson's Poetry}

A similar device underpins 'The Bow in the Cloud' (FR, pp. 8o-6): a more ambitious, four-part poem that is the final, climactic text in Nicholson's debut volume. The story of the Flood (Genesis 6-9) is transferred to coastal Cumberland and a familiar Nicholsonian topography of 'pitshafts' and 'mines' (p. 8o). Although 'The Bow in the Cloud' offers a continuation of Nicholson's strategy of biblical transportation, however, the poem also points towards developments in his theological representation of place and space. Nicholson's regionalized vision of the Flood problematizes the tripartite spatial hierarchy implicitly constructed in both 'Egremont' and 'Whitehaven' in that in 'The Bow in the Cloud' both urban and rural topographies are covered by water. The sea is said to burst 'through the dykes like a fleet of tanks, I Smashes like a heel on a matchbox the roofs of the town'; it then moves into green space and 'floods the lowlands and the dales, | And fills the ghylls and gullies of the fells' (p. 84). Nicholson, therefore, moves away from a conceptualization of region in which the built and the natural are completely divorced and moves towards a more unified, boundless understanding of geographical space.

Connected with this, the poem offers a heightened concentration on the interiority of phenomena: an ontological shift that is exemplified by the way in which the flood water is said to travel 'as if charged with dynamite' (p. 85). Nicholson's chosen verb resonates with Gerard Manley Hopkins's sonnet 'God's Grandeur' and the famous articulation of how 'The world is charged with the grandeur of God'. ${ }^{20}$ Nicholson's work as an anthologist and critic highlights his knowledge of Hopkins's poetry, and, in selecting this particular verb, he can be seen to be gesturing towards an understanding of physical matter that broadly corresponds with Hopkins's theory of 'inscape'; that is to say, Nicholson begins to move towards a way of perceiving the individual or essential quality of an object, or what the spatial theologian Philip Sheldrake describes as 'the interior dynamism' of things. ${ }^{21}$ The fact that Nicholson's simile is completed by the noun 'dynamite' does not undermine this reading but, rather, reinforces the sense of wholeness suggested by the dismantling of imagined spatial frontiers, in that the natural and the man-made are collapsed into the single image. Although Nicholson implicitly alludes to the opening line of 'God's Grandeur', however, there remains a fundamental distinction between Hopkins's image and his own theological emphasis on materiality. Whereas, in the words of Justus George Lawler, Hopkins's poem focuses on 'unvarnished, unembellished' actuality to celebrate 'the absolute oneness of deity', 'The Bow in the Cloud' remains

\footnotetext{
${ }^{20}$ Gerard Manley Hopkins, 'God's Grandeur', in The Poetical Works of Gerard Manley Hopkins, ed. by Norman H. Mackenzie (Oxford: Clarendon Press, I990), p. I39.

21 Philip Sheldrake, Spaces for the Sacred: Place, Memory and Identity (London: SCM Press, 200I), pp. 66-7. In his 1942 Anthology of Religious Verse, Nicholson includes three poems by Hopkins: 'Hurrahing in Harvest' (pp. 2O-I), 'The May Magnificat' (pp. 24-6), and 'I Wake and Feel the Fell of Dark' (p. 43).
} 
founded upon the imaginary vision of an extraordinary apocalyptic event. ${ }^{22} \mathrm{In}$ other words, Nicholson replaces the tripartite spatial model with a dualistic understanding in which heavenly and earthly spaces remain separated in the practice of everyday life.

Significantly, however, the retelling of the Flood necessarily requires a human presence, and in 'The Bow in the Cloud' Nicholson assigns the role of Noah to 'Old Tyson [...] a farmer | A statesman of the fell' (p. 8I). In the fourth and final section of the poem, 'the new moon drops into the sky | And hangs for the first time on the pull of the earth'; and 'Tyson steps onto Scawfell Pike', from where he sees the rainbow form in the thickening fog and gathering cloud (p. 85). At this highest point in England, Tyson experiences a quasi-mystical sense of the transcendent, as his post-diluvian Christian prayer begins with him raising 'his eyes beyond the perspectives of the sea' (p. 85, my italics). Yet, crucially, the poem ends with a restoration of material everydayness:

The moon hangs high in the bright sky,

The bow fades in the cloud, the mist

Rises like thanksgiving, the sea returns to its routine,

And Tyson buckles his horse to the shafts of the plough. (p. 86)

The poem draws to a close with a Heideggerian image of telluric reconnectedness as Tyson is shown to return to his native terrain. More than this, it is particularly significant that the poem ends with a focus on objects as the autochthonous dweller is shown preparing to work this land. In returning home after the Flood, Tyson is acutely aware that his earthly inhabitation of this green place is at the mercy of God; by extension, if God has created Tyson and, in turn, Tyson has gathered together the material for the construction of the plough, then the object itself can be seen to be 'charged' with the presence of God. Both Five Rivers and 'The Bow in the Cloud' climax with an emphasis on the second of the key tropes in Nicholson's theological poetics of place and space: the representation of the relationship between the material landscape, human inhabitation, and Christian belief.

This triangulated relationship emerges as a dominant feature of Nicholson's second Faber volume, Rock Face, and ultimately leads to a redefining of the dualistic spatial model set up in 'The Bow in the Cloud'. 23 'The Land under the Ice' (pp. 8-I2) is a poem that documents the coming of the Ice Age and its shaping of the precipitous Cumbrian terrain: 'Then wakes the ice, and creaks and heaves its back, | And shakes the loose screes with its haunches'; 'the angular wild northern ice | Takes a grip upon the shrunken land'. The poem is

\footnotetext{
22 Justus George Lawler, Hopkins Re-Constructed: Life, Poetry, and the Tradition (New York: Continuum, I998), p. 97 .

${ }_{23}$ Norman Nicholson, Rock Face (London: Faber and Faber, 1948). Further references to individual poems within this collection will be given in the text.
} 


\section{I78 Topographical and Theological Space in Nicholson's Poetry}

concerned with the geological evolution of the regional landscape; but the introduction of the shadowy and unnamed character of the 'Statesman' (p. 8) serves to open up thinking about what it means to dwell on the rock. In the opening section of the poem, the figure is forced to abandon his native ground on witnessing 'the huge hulk of the wolving snow | [. . ] crush | The cottage roofs and lintels, [and] push | The funnelled chimneys down'; and in Section II the Statesman is shown to experience a period of nomadic placelessness as he resorts to feeding 'on shoots | Of alpine cresses' and the 'leaves of creeping willow' in an unfamiliar landscape of 'southern ghylls' (p. io). Miraculously, however, he manages to survive 'ten thousand years' (p. Io) of seismic change, and in the third and final section of the poem the Statesman is shown returning 'to his birth-right land | Under the crag's new gable-end' (p. I I). ${ }^{24}$ In these lines, the rock itself symbolically provides the physical site in which the Statesman is able to dwell; to draw upon the Heideggerian thinking of Gaston Bachelard, the rock allows the Statesman to 'take root' and to define his own 'corner of the world'. ${ }^{25}$

For Gardner, the portrayal of the Statesman carries an Old Testament allusion and invites comparison with the figure of Methuselah, who, according to the Book of Genesis, lived 'nine hundred sixty and nine years' (Genesis 5. 27); but, for the most part, 'The Land under the Ice' is not an explicitly Christian poem. ${ }^{26}$ The text can be read, however, as a contribution to Nicholson's exploration of the relationship between his understanding of geological process and his personal Christian faith. To that end, it is a poem which is implicitly informed by a belief previously expressed in the topographical prose book Cumberland and Westmorland (I949):

It has been said that when God made England His finger touched but did not press. This certainly is not true of Cumberland and Westmorland. He pressed there all right. What is more, He used His nails. And the nails were ice. ${ }^{27}$

More specifically, the poem ends with a monologue in which the Statesman indicates that 'in the white night of the bone' he has heard a series of gods: the 'senile north gods', the 'wind-god', the 'wheeling sun-god', and the 'dawn-god' (p. I2). He concludes this list, however, with the revelation that 'always in the skull-pit have I known | The silent god within the silent rock' (p. I2). As a result, 'The Land under the Ice' confirms the imaginative shift first intimated at the

\footnotetext{
24 As Wordsworth explains in a letter to Charles James Fox in I80i, the term 'statesman' has a specific resonance within the Lake District, referring to 'proprietors of small estates, which have descended to them from their ancestors'; William Wordsworth, letter to Charles James Fox, I4 January i8or, in The Letters of Wordsworth and Dorothy Wordsworth, ed. by Ernest de Selincourt, I: The Early Years, I787-I805, rev. by Chester L. Shaver, 2nd edn (Oxford: Oxford University Press, I967), pp. 312-I5 (p. 314).

${ }_{25}$ Gaston Bachelard, The Poetics of Space, trans. by Maria Jolas (Boston, MA: Beacon Press, 1964; repr. 1994), p. 4 .

26 Gardner, p. 69.

27 Norman Nicholson, Cumberland and Westmorland (London: Robert Hale, I949), p. 42.
} 
end of 'The Bow in the Cloud'; it underlines Nicholson's movement away from the regional spatialization of biblical narratives and towards a theological reading of the area's geological topography. It is a perceptual shift towards the material actuality of things, which, in turn, leads to an implicit engagement with what John V. Taylor calls 'the ultimate paradox of spiritual reality': the idea that by 'being simply what they are and no more, things act as clues or symbols, pointing to what lies beyond themselves'. ${ }^{28}$ Instead of purposefully looking 'beyond' things, though, in the hope of a sign of transcendental possibility, Nicholson begins to look at and in the physical world of immediate experience; he begins to perceive the world as a deified space.

In his critical monograph on Nicholson's early work, Gardner critiques 'The Land under the Ice' and argues that 'the intrinsic impersonality of the subject precludes imaginative involvement in the poem as a whole' ${ }^{29}$ It is a reading that is partially valid in that, as with 'Old Tyson' in 'The Bow in the Cloud', the unparticularized figure of the Statesman primarily operates as a symbolic abstraction. Yet Gardner does not acknowledge the pivotal role that the poem plays in the development of Nicholson's Christian poetics of place and space; more precisely, Gardner does not recognize how Nicholson's organization of the textual space of the published volume contributes to the ongoing articulation of a theology of place. The final seven quatrains of 'The Land under the Ice' appear on a verso page of Rock Face, and, directly opposite, Nicholson places the complete text of 'A Street in Cumberland' (p. I3). In this shorter poem he presents a modern urbanized environment in which the inhabitants remain unaware of both the spatial history of the location in which they dwell and the fact that on this site once 'stood a farm | Two hundred years on its own land'. The third-person speaker indicates that the façades of the terraced houses are made of 'rough-cast' but goes on to direct the reader to a concealed architectural detail:

Come round to the back and you will find

The old, uncovered walls - slate bosses

Two foot by two, with cobble-ducks for gable-end (p. 13)

The reference to the 'gable-end' invites the reader to draw a direct link between the modern-day inhabitant of this Cumberland street and the Methuselan Statesman whose process of telluric reinhabitation is described on the facing page of the volume. In this shorter poem, then, the abstractions of 'The Land under the Ice' — and 'The Bow in the Cloud' — are concretized as the cardinal ideas of authentic being and dwelling are examined within a contemporary, urbanized setting of terraced houses, brick-walled gardens, and hydrangeas.

\footnotetext{
${ }^{28}$ John V. Taylor, The Christlike God (London: SCM Press, I993), p. 23.

29 Gardner, p. 70.
} 
Nicholson uses the material space of the published collection to set up an implied intratextual relationship between these two poems; and he moves away from the conceptual separation of geographical spaces, as evidenced in his early poems, and towards a holistic understanding of the porous relationship between the urban and the rural that is underpinned by geological knowledge. By extension, although 'A Street in Cumberland' does not contain any explicitly Christian content and could be read as a portrait of a secularized built environment, the theological foundations for Nicholson's spatial thinking have already been established. As a result, when Nicholson offers a vision of 'the loins of the rock that bred' a modern Cumberland dwelling-place (p. I3), he implicitly prompts the reader to reflect upon 'the Christian substratum' underpinning his meditations upon the nature of earthly experience. ${ }^{30}$ That is to say, the reader is invited to dismantle the perceived spatial boundaries between the rural and the urban and to consider all places to be of equal significance and value within the oneness of lived space created by God. When 'The Land under the Ice' and 'A Street in Cumberland' are read as companion texts, therefore, Nicholson can be seen to be moving towards an autochthonous poetics of place and space that is theologically and geologically informed, geo-specific, and predicated on the everyday rather than the extraordinary.

So far, this essay has focused on Nicholson's regional transplantation of biblical narratives and the principle of telluric connectedness. The growing focus on the actuality of the quotidian underpins the third key characteristic of Nicholson's early theological-topographical poetics: the return to a geographically located, first-person poetry of place and space that was first intimated in 'Now That I Have Made my Decision'. During the i95os Nicholson used a series of national radio broadcasts and prose articles to examine the nature of provincial experience and, by extension, to theorize the role of the provincial poet. ${ }^{31}$ It was a project constructed on the imperative to strip the term 'provincial' of the pejorative associations first engendered by Dr Johnson and which had since become embedded within cultural assumptions about space and centre-periphery relations. From this etymological foundation Nicholson went on to trace 'the provincial tradition' in English literature, thereby positioning his own geopoetics within a canonical line that he claims included, amongst others, Wordsworth, George Eliot, Arnold Bennett, and D. H. Lawrence. ${ }^{32}$ Overall,

\footnotetext{
30 Gardner, p. 29 .

31 See, for example, 'Millom Delivered', Listener, 24January i952, pp. I38-50; 'On Being a Provincial', Listener, I2 August I954, pp. 248-9; and 'Where England Begins', Listener, 26 June I958, pp. I05I-4. Nicholson's provincial project can be seen to climax with the publication of Provincial Pleasures (London: Robert Hale, I959), a prose book that eludes generic categorization but documents everyday life in the town of 'Odborough' (Millom).

32 Norman Nicholson, 'The Provincial Tradition', Times Literary Supplement, I5 August i958, p. xix.
} 
Nicholson began to codify what might be labelled a model of positive provincialism: a poetic celebration of the commonplace.

This series of critical writings can be placed within the framework of midtwentieth century literary history and can be interpreted as Nicholson's attempt to provide a conceptual justification for his inclusion on Eliot's prestigious poetry list at Faber. At the same time, the increased focus on everyday life can be seen to have been informed by developments in Nicholson's theological thinking. According to Gardner, Nicholson, as a young adult, "believed in a God "continuously in touch with his creation"'; but Nicholson's return to the church was problematised by the great difficulty he encountered in grasping 'the historicity of the Incarnation'. ${ }^{33}$ It is a difficulty that is manifested in Nicholson's early poetry, as the poems in both Five Rivers and Rock Face do not reflect upon the experience of embodied situatedness; that is to say, the poems do not explore what it means to be a corporeal being living in a particular place at a specific moment in history. Nicholson's self-conscious development of a theory of positive provincialism, therefore, can be understood to be an environment in which he consolidates his acceptance that 'The Word became flesh and we have beheld his glory' (John I. I4).

This theological reading of Nicholson's provincial project can be supported by turning to the spatial thinking of John Inge. In A Christian Theology of Place (2003), Inge establishes a clear distinction between the spatialities to be located within the Old and New Testaments. According to Inge, 'place is a very important category in the Old Testament [in] that the narrative supports a three-way relationship between God, people and place in which all three are essential'. ${ }^{34}$ More particularly, Inge identifies how this tripartite relationship is played out within the sacred sites of the Holy Land and Jerusalem, and he indicates how the process of inhabitation means that these locations are to be understood to be 'storied places' rather than placeless spaces (p. 36). Inge goes on to argue that in the New Testament 'there is no longer concentration upon' these geo-specific sites; but the importance of place is reasserted, and enriched, as 'the locus of God's relations with humanity' is defined through the bodily being of Christ (p. 52). For Inge, the incarnation 'initiates an unprecedented celebration of materiality' (p. 52), and the actual experience of located being is thereby integral to Christian belief: 'Seen in an incarnational perspective, places are the seats of relations or the place of meeting between God and the world' (p. x).

The way in which Nicholson's model of positive provincialism is informed by both literary self-positioning and theological belief can be traced in the series of

\footnotetext{
33 Gardner, p. 28.

${ }^{34}$ John Inge, A Christian Theology of Place (Aldershot: Ashgate, 2003), p. x. Further references will be given in the text.
} 
Millom poems that appear towards the beginning of The Pot Geranium. ${ }^{35}$ The titles of these poems highlight the way in which Nicholson's literary cartography is taken to new levels of microscopic detail: 'Millom Old Quarry' (pp. I I-I2), 'Old Main Street, Holborn Hill, Millom' (pp. I3-I4), 'On a Proposed Site for Council Houses, Holborn Hill Ward, Millom Rural District' p. I5). For the first time, then, Nicholson offers the reader an extended portrait of the rich materiality of his immediate environment. In 'Millom Old Quarry', for example, the organic and the industrial are brought together in the lived space of Nicholson's home town as the speaker describes how 'The rocks cracked to the pond, and hawthorns fell | In waterfalls of blossom' (p. i I). These are poems in which Nicholson documents the interconnectedness of all things: dykes and roofs; grass and concrete ('On a Proposed Site', p. I5). Unlike the place-name poems in Five Rivers, however, these poems offer a subjective textual mapping of place, as the introduction of a first-person speaker leads to the articulation of an embodied, multi-sensory, and temporally layered engagement with place. 'On a Proposed Site' begins, for instance, with the speaker recalling how 'Many a spring, passing this dyke, I picked the wild cherry, | Oozing its beads of milk on branches black with soot' (p. I5). As a result, Nicholson begins to use the poem as a space in which to describe the actuality of all objects and to record the physical activity of the self moving through the world. In other words, Nicholson, through his acceptance of the incarnation, begins to offer a necessarily subjective celebration of 'the thick texture of human life'. ${ }^{36}$

The intersection of Nicholson's theological, topographical, and literary thinking is also evident in the title poem of his third volume; a forty-six line text that would emerge as a signature set-piece. 'The Pot Geranium' begins with the detached documentation of an autumnal townscape in which 'an acid wind | Dissolves the leaf-stalks of back-garden trees' and in which 'chimneys with their fires unlit | Seem yet to puff a yellow smoke of poplars' (pp. 9-io). Although the place remains unnamed, the reader is offered particularized topographical description; and, significantly, there is a fleeting reference to the perceived secularization of this social space, as it is noted how 'the model bakery' was once 'a Primitive Methodist Chapel' (p. 9). The dominant motif within the first section of the poem, however, is the oscillation between images of enclosure and boundlessness. It is a spatial preoccupation that is symbolized by the speaker's description of a 'box-kite': the kite represents spatial mobility and liberation as it is shown to be released into the limitlessness of ethereal space 'like a flight of racing pigeons | Slipped from their basket in the station yard'; ultimately,

\footnotetext{
35 Norman Nicholson, The Pot Geranium (London: Faber and Faber, 1954). Further references to individual poems within his collection will be given in the text.

36 Inge, p. 53 .
} 
though, the kite remains anchored in the fixity of place as it 'Strains and struggles on its leash', which, in turn, is controlled by human hand in the form of 'unseen boys' (p. 9).

The second part of the poem is marked by a narratorial shift, in that a firstperson speaker is introduced for the first time: 'I turn from the window | (Letting the bobbins of autumn wind up the swallows) | And lie on my bed' (p. Io). It becomes clear that the speaker has been documenting the 'Green slated gables' and 'old quarry' (p. Io) of the town from his bedroom window; and, in Bachelardian terms, Nicholson can be seen to be exploring the 'dialectics of outside and inside space' and the porosity of the relationship between the 'intimate space' of the domestic interior and the shared social space of the world beyond the window. ${ }^{37}$ The speaker goes on, however, to apply ideas of spatial enclosedness and limitlessness to his own corporeal self as he records how 'Thighs and spine | Are clamped to the mattress and looping springs | Twine round my chest and hold me' (p. 9). Yet, in spite of this physical restriction, Nicholson's speaker remains sensitive to the imaginative potentiality presented by a sense of spatial boundlessness. Although the 'white walls' of the room appear to collapse around his prostrate body, he notes that, significantly, there remains 'a flap for the light to blow through' (p. 9). This gap may be narrow, but it opens up a necessary physical and imaginative passage between inside and outside space, allowing the speaker to retain a sense of being-in-the-world. Even within this environment of inactivity, the speaker is able to experience sensation: he feels 'the air' move across his 'face like spiders' and he can 'see the light | Slide across the plaster' (p. 9). He is resigned to the fact that 'wind and sun | Are mine no longer, nor have I kite to claim them' (p. 9); but, crucially, he is not positioned within a domestic environment of impenetrable boundedness or absolute stagnancy. Instead, the retreat to a site of extreme intimacy and solitude allows the speaker to develop a heightened, almost hallucinatory, sense of perception.

'The Pot Geranium' ends with the first-person speaker offering an unambiguous declaration of a commitment to a specific location and a particular way of being:

\footnotetext{
And what need therefore

To stretch for the straining kite? - for kite and flower

Bloom in my room for ever; the light that lifts them

Shines in my own eyes, and my body's warmth

Hatches their red in my veins [...]

My ways are circumscribed, confined as a limpet

To one small radius of rock; yet

I eat the equator, breathe the sky, and carry

The great white sun in the dirt of my finger-nails. (p. 9)
}

37 Bachelard, pp. 21 I, 3 . 


\section{I84 Topographical and Theological Space in Nicholson's Poetry}

In these final lines Nicholson pulls together the interwoven preoccupations that this article has identified and has attempted to unpick. The climax to 'The Pot Geranium' can be placed in a literary-historical context and can be read as an articulation of Nicholson's manifesto for positive provincialism; he confirms that his own poetry will be built on the documentation of an authentic, everyday engagement with the physical, earthy matter of a particular place. Connected with this, the poem can also be read as Nicholson's expression of his own embodied experience and the way in which his adolescent contraction of tuberculosis resulted in the delimiting of the possibilities of spatiality and mobility. This biographical interpretation necessarily intersects with a spatial reading of the text. Ultimately, 'The Pot Geranium' incorporates the geographical within an archetypal phenomenological dissolution of the Cartesian separation of subject and world that, in turn, highlights Nicholson's imaginative interest in interrogating what Maurice Merleau-Ponty calls 'the synthesis of one's own body'; that is to say, Nicholson uses poetry to collapse the distinction between corporeal self and world and, through a series of synaesthetic conceits, highlights how 'our body is not primarily in space: it is of it'. ${ }^{38}$ In 'The Pot Geranium', therefore, Nicholson uses the physical self as a site in which to further the model of spatial limitlessness towards which he works in his first two volumes of poetry.

Finally, the end of 'The Pot Geranium' can also be understood within the theological context created by Nicholson's growing acceptance of the incarnation and, by extension, his increasing fascination with the declaration that 'the whole earth [shall] be filled with his glory' (Psalm 72. I9, my italics). By expressing a phenomenological collapse of the perceived demarcation between bodily and geographical space, therefore, Nicholson confirms his belief that everyday spatial practice necessarily involves the inhabitation of, and the movement through, space that, in the words of Inge, has been "Christified" by the incarnation'. 39 This focus on the physical situatedness of the embodied self is developed further in The Pot Geranium in such poems as 'Weather Ear' (p. I6), 'From a Boat at Coniston' (p. 25), and 'The Buzzer' (p. 53), and feeds into an overarching spatial project that emphasizes the Affirmative Way. To draw on the thinking of Sheldrake, Nicholson includes his own body within the epiphanic revelation that 'God's presence-as-action directly and intimately touches the within of each thing. God is the source of, and the goal of, each thing in its interior dynamism'. ${ }^{40}$ In his third Faber volume, then, Nicholson articulates an understanding of space in which the perceived borders between heavenly and earthly realms are dissolved.

38 Maurice Merleau-Ponty, Phenomenology of Perception, trans. by Colin Smith (London: Routledge \& Kegan Paul, I962), p. I7I.

39 Inge, p. 57.

40 Sheldrake, pp. $66-7$. 
This essay has explored the way in which Nicholson's early career as a Faber writer is characterized by a movement towards an incarnational, first-person poetry, a poetry founded upon an understanding of embodied being and dwelling that situates Cumberland places within the absoluteness of 'Christified' space and which, by extension, celebrates the divine texturality of all matter. The critical rehabilitation of Nicholson, though, necessitates engagement with the poet's entire œuvre, and there remains a need to draw upon phenomenological thinking and spatial theory to offer new readings of Nicholson's final two volumes, A Local Habitation and Sea to the West. ${ }^{41}$ In these collections Nicholson expands his project of positive provincialism to offer a vision of the intersubjective, rather than purely personalized, experience of everyday life in Millom: a shift in emphasis that opens up the possibility of a socio-spatial reading. Yet, crucially, Nicholson's vision of a geo-specific social interconnectedness is reliant upon the retrospective reconstruction of a way of life that ceased to exist after the dismantling of Millom's iron industry. ${ }^{42}$ As a result, these late poems can be read as a nostalgic yearning for a way of being characterized by a sense of what the phenomenological geographer Yi-Fu Tuan might describe as 'group belongingness'. ${ }^{43}$ These poems of pastness also emerge, however, from the fact that Nicholson's mature understanding of the material world is destabilized and even ruptured by the town's diminishing natural resources and the resultant process of deindustrialization. Ultimately, then, even these late poems of socio-spatial nostalgia could, and should, be read within the incarnational framework provided by Nicholson's earlier development of a theological poetry of place and space.

In constructing these spatial readings, and reappraising the writer's critical reputation, it will be vital to examine the way in which Nicholson selfconsciously positions his own work within the intertextual contexts of both Cumbrian literary history and the English tradition of the poetry of place. At the same time, it will be essential to locate Nicholson's work within contemporaneous contexts and to explore the imaginative intersections and distinctions between his own geo-poetry and that of his provincial peers R. S. Thomas and George Mackay Brown. The consideration of spatial and phenomenological thinking will facilitate further understanding of Nicholson's contribution to a significant, yet relatively neglected, strand of post-war British poetry: that poetry which articulates the contradictions and tensions embedded within an experience of being and dwelling that is both geographically rooted and theologically informed.

\footnotetext{
${ }^{41}$ Norman Nicholson, A Local Habitation (London: Faber and Faber, 1972) and Sea to the West (London: Faber and Faber, I98I).

${ }^{42}$ Nicholson documents the process of localized deindustrialization in twin poems: 'On the Closing of Millom Ironworks', in A Local Habitation, pp. 46-7; and 'On the Dismantling of Millom Ironworks', in Sea to the West, pp. 49-50.

43 Yi-Fu Tuan, Place, Art, and Self(Santa Fe, NM: Center for American Places, 2004), p. 4o.
} 


\section{Topographical and Theological Space in Nicholson's Poetry}

Query

[Copy-ed1] Changed to reflect the date of writing/first performance, since publication dates are given in the footnote. Please confirm that the dates of composition are correct for A Match for the Devil and Birth by Drowning. 